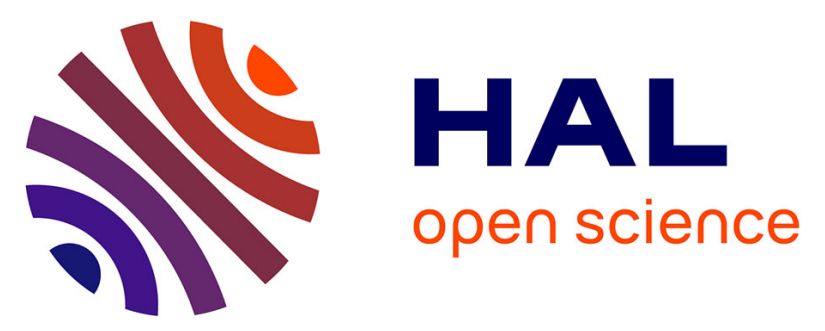

\title{
Efficacy of zinc salts to protect glass against atmospheric alteration. Part II: Possible passivation mechanisms
}

\author{
Fanny Alloteau, Odile Majérus, Valentina Valbi, Isabelle Biron, Patrice
}

Lehuédé, Daniel Caurant, Grégory Lefèvre, Antoine Seyeux

\section{- To cite this version:}

Fanny Alloteau, Odile Majérus, Valentina Valbi, Isabelle Biron, Patrice Lehuédé, et al.. Efficacy of zinc salts to protect glass against atmospheric alteration. Part II: Possible passivation mechanisms. Journal of the American Ceramic Society, 2021, 104 (5), pp.2052 - 2065. 10.1111/jace.17589 . hal03379560

\section{HAL Id: hal-03379560 \\ https://hal.science/hal-03379560}

Submitted on 18 Oct 2021

HAL is a multi-disciplinary open access archive for the deposit and dissemination of scientific research documents, whether they are published or not. The documents may come from teaching and research institutions in France or abroad, or from public or private research centers.
L'archive ouverte pluridisciplinaire HAL, est destinée au dépôt et à la diffusion de documents scientifiques de niveau recherche, publiés ou non, émanant des établissements d'enseignement et de recherche français ou étrangers, des laboratoires publics ou privés. 
Efficacy of zinc salts to protect glass against atmospheric

\author{
alteration. Part II: Possible passivation mechanisms.
}

Fanny Alloteau ${ }^{* \dagger 1,2}$, Odile Majérus ${ }^{2}$, Valentina Valbi ${ }^{\ddagger 1,2}$, Isabelle Biron ${ }^{1}$, Patrice

Lehuédé $^{1}$, Daniel Caurant ${ }^{2}$, Grégory Lefèvre ${ }^{2}$ and Antoine Seyeux ${ }^{2}$

${ }^{1}$ Centre de Recherche et de Restauration des Musées de France, PSL Research

University, CNRS, Institut de Recherche de Chimie Paris (IRCP), F-75001 Paris,

France

${ }^{2}$ Chimie ParisTech, PSL Research University, CNRS, Institut de Recherche de Chimie Paris (IRCP), F-75005 Paris, France

\begin{abstract}
To investigate the origin of the protection effect of zinc salts against glass atmospheric alteration, the speciation of $\mathrm{Zn}^{2+}$ ions on glass according to the deposit protocol and the $\mathrm{Zn}^{2+}$ surface concentration, and its change over time, was investigated in the light of the respective performances of the treatments.

\footnotetext{
*corresponding author - alloteau.fanny@gmail.com

${ }^{\dagger}$ current affiliation: Rathgen-Forschungslabor, Staatliche Museen zu Berlin - Stiftung Preußischer Kulturbesitz (SMB-

${ }^{\ddagger}$ current affiliation: Laboratoire Géomatériaux et Environnement (LGE) - Université Gustave Eiffel, F-93160 Noisy-Le-
} SPK), Berlin Grand, France

This article has been accepted for publication and undergone full peer review but has not been through the copyediting, typesetting, pagination and proofreading process, which may lead to differences between this version and the Version of Record. Please cite this article as doi: 10.1111/JACE.17589
\end{abstract}

This article is protected by copyright. All rights reserved 
In that respect, a combination of various characterization methods of the glass surface and near-surface was used before and after ageing experiments (temperature, relative humidity ( $\mathrm{RH})$ control) of the $\mathrm{Zn}$ treated glass. Different Zn-species could be observed on the surface of the treated glass: chemisorbed species, physisorbed species and precipitated hydroxide phases, their respective distribution being highly dependent on the nature of the treatment and on the $\mathrm{Zn}^{2+}$ surface concentration. GI-XAS (Zn K-edge) and Tof-SIMS experiments pointed out the conversion by thermal activation of these surface species into chemisorbed species inserted in the glass network in the near-surface. The chemisorbed species appear to be the most effective ones for the glass protection, possibly by making the surface less soluble, less hydrophilic and even by acting as a diffusion barrier.

\section{INTRODUCTION}

The protective action of zinc salts against the atmospheric alteration or the aqueous dissolution of silicate glasses has been exploited in an industrial context for decades, whether for the protection of freshly produced float glass during their transport and storage, ${ }^{1-4}$ or for the protection of glasswares during washing in dishwasher. ${ }^{5-8}$ Indeed, the storage of float glass in atmosphere generates aggressive chemical conditions because humidity penetrates the space between the glass plates and condenses by capillarity around the polymer beads used as interlayers. The rising of the $\mathrm{pH}$ due to this small volume of static water induces corrosion of the silicate network, which may be visible as inhomogeneous stains, loss of transparency and/or iridescence. Initial stages of corrosion may not be visible but still hamper the further processing, for example by causing adherence issues to coatings. ${ }^{3,4}$ On the other hand, chemical conditions are also aggressive in the dishwasher due to high temperature (about $60^{\circ} \mathrm{C}$ ) and prolonged exposure to high $\mathrm{pH}$ detergents. Consequently, glassware surface gets attacked and dissolved silicate and aluminate materials deposit on it, inducing clouding and iridescence. In addition, chemical builders in the cleaning product chelate and remove stabilizing ions from the glass surface (such as $\mathrm{Ca}^{2+}$ and $\mathrm{Mg}^{2+}$ ),

This article is protected by copyright. All rights reserved. 
reducing its chemical resistance. ${ }^{5,9}$ Zinc salts have proven to be efficient in both situations, although the underlying mechanisms are not clearly known. Hypotheses have been put forward, all relying on chemical reaction of zinc salts with the glass surface, making this surface less prone to hydration. $\mathrm{Zn}^{2+}$ ions would adsorb on the glass surface and occupy network-forming positions that improve its mechanical and chemical resistance ${ }^{5,10}$ and/or $\mathrm{Zn}^{2+}$ ions would induce a thin protective zinc silicate layer acting as diffusion barrier. ${ }^{11}$ In the literature, such a well-defined zinc-silicate layer does not seem to have been observed in ambient conditions (ambient vapor pressure, temperature $\left.(\mathrm{T})<100^{\circ} \mathrm{C}\right)^{12}$ but it has been found a strong $\mathrm{Zn}$-enrichment at the surface, together with the diffusion of $\mathrm{Zn}^{2+}$ ions from the surface to within the glass, when a zinc-free glass was immersed in a zinc solution or when the surface of a float glass was treated by an industrial Zn-bearing solution. ${ }^{10,13}$ This Zn-enriched layer retards the release of soluble elements such as $\mathrm{Na}$ and $\mathrm{B}$ in borosilicate glass. ${ }^{10,11}$ On the other hand, $\mathrm{ZnO}$ in the glass composition improves the chemical durability, although it is not clear if this is due to a surface layer effect or to $\mathrm{ZnO}$ strengthening the bulk glass structure. ${ }^{11,14}$ Recently, by using a continuous gravimetric technique to measure water sorption isotherms, Nunes de Carvalho et al. demonstrated that adsorbed $\mathrm{Zn}^{2+}$ ions reduce the water corrosion flux, which they explained by the decrease of the hydrophilic character of the surface, rather than by diffusion barrier effect. ${ }^{15}$

Another situation where zinc salts have proven successful as glass corrosion inhibitors is described in the part I of this study, ${ }^{16}$ namely the atmospheric alteration of glass in unsaturated humidity (relative humidity $(\mathrm{RH})<100 \%)$ in conditions excluding liquid water condensation on the surface. The treatment consists in spraying a zinc salts-bearing alcoholic solution on the glass surface. By this way, the deposit of a small amount of about 0.1 to $1.5 \mu \mathrm{g} / \mathrm{cm}^{2}$ of $\mathrm{Zn}^{2+}$ ions was sufficient to reduce the atmospheric alteration kinetics of three alkali lime silicate compositions representative of the cultural heritage, at $40^{\circ} \mathrm{C}$ or $80{ }^{\circ} \mathrm{C}$ and $85 \mathrm{RH} \%$, in the timescale of the experiments $\left(6\right.$ months at $40^{\circ} \mathrm{C}$ and 6 days at $\left.80^{\circ} \mathrm{C}\right)$. This treatment could be potentially valuable in protecting unstable glass artefacts from atmospheric alteration in museums, because of the very few amounts of deposited material, its simplicity of use and its non-

This article is protected by copyright. All rights reserved. 
toxicity. This glass protection approach is an alternative to the more common approach relying on dense, adherent coatings that act as diffusion barriers, such as silica or hybrid sol-gel coatings that are currently investigated in the cultural heritage community. In the present paper, by the mean of complementary experiments based on an alternative zinc treatment to the spray treatment, and of complementary surface analysis techniques, the speciation and distribution of $\mathrm{Zn}^{2+}$ ions after their reaction with the surface is studied and the possible mechanisms of the protection against atmospheric alteration are discussed.

\section{EXPERIMENTAL PROCEDURES}

Experiments were performed on the glass composition $\mathbf{A}$ (wt\%: $\mathrm{SiO}_{2} 71, \mathrm{Na}_{2} \mathrm{O}$ 11, $\mathrm{K}_{2} \mathrm{O}$ 11, $\mathrm{CaO} 5, \mathrm{MgO}$ $1, \mathrm{Al}_{2} \mathrm{O}_{3}$ 1) studied in the part I of this study. ${ }^{16}$ Details regarding its fabrication, the preparation of samples (polished plates and powder) and cleaning procedure are described elsewhere. ${ }^{17}$

\section{$2.1 \quad \mathrm{Zn}(\mathrm{II})$ deposits on glass surface}

Two types of treatments are studied in this paper. The first one is the spraying treatment described in the part I of this study ${ }^{16}$ (treatment at ambient temperature) and considered for the protection of ancient glass objects under the museum atmosphere. The second one is a treatment by immersion in a hot zinc salt solution, which was investigated for comparison purposes with the first one to better understand the origin of the zinc protective effect.

\subsubsection{Spraying treatment}

The spraying treatment was performed on the polished face of a glass plate freshly cleaned, using a solution of zinc nitrate hexahydrate $\left(\mathrm{Zn}\left(\mathrm{NO}_{3}\right)_{2} \cdot 6 \mathrm{H}_{2} \mathrm{O}\right.$, Sigma-Aldrich) at $0.61 \mathrm{mM}$ or at $9 \mathrm{mM}$ in absolute ethanol.

This article is protected by copyright. All rights reserved. 


\subsubsection{Alternative treatment: treatment by immersion}

The treatment by immersion in a hot zinc salt solution was adapted from Ref. ${ }^{15}$ and performed for a second batch of glass plates to allow comparison with the spraying treatment. Aqueous solution containing $\mathrm{Zn}^{2+}$ ions at a concentration of $1.2 \mathrm{mM}$ was prepared by diluting reagent grade zinc nitrate hexahydrate $\left(\mathrm{Zn}\left(\mathrm{NO}_{3}\right)_{2} \cdot 6 \mathrm{H}_{2} \mathrm{O}\right.$, Sigma-Aldrich) in milliQ water heated to $60^{\circ} \mathrm{C}$ using a stirring hot stage, the temperature accelerating the adsorption kinetics of $\mathrm{Zn}^{2+}$ on glass surface. ${ }^{18}$ Glass plates were immersed for $15 \mathrm{~s}$ in the hot $\mathrm{Zn}^{2+}$ bearing solution, then rinsed for $10 \mathrm{~s}$ with a continuous flow of cold milliQ water, finally they were dried for $10 \mathrm{~s}$ with an air flux $\left(\mathrm{T}<40^{\circ} \mathrm{C}\right)$. Glass powders were also subjected to an immersion treatment to evaluate the modifications of the surface charges with a zinc treatment (experiments described further below): after $15 \mathrm{~s}$ of immersion in the hot $\mathrm{Zn}^{2+}$ bearing solution, the powders were vacuum filtered using a Buchner funnel. The filtered glass particles, which were collected by deposition on a filter paper, were rinsed with a controlled amount of milliQ water and dried at $50{ }^{\circ} \mathrm{C}$ for $24 \mathrm{~h}$.

\subsubsection{Quantification of deposited $\mathrm{Zn}$ (II) on glass surface}

After surface treatment, the surface amount of deposited $\mathrm{Zn}^{2+}$ was evaluated. Details for the quantification of deposited $\mathrm{Zn}^{2+}$ on glass plates are given in the part I of this study $\left({ }^{16}\right.$ - Supplemental Materials, section $\mathrm{S}$ 1.1). For glass powders, the mean concentration of deposited $\mathrm{Zn}^{2+}$ ions after the immersion treatment was measured by wet dosage: after desorbing the $\mathrm{Zn}^{2+}$ ions from glass surface with an acidic solution (diluted $\mathrm{HCl}$ in milliQ water), the solution was sampled and analyzed by Inductive Coupled Plasma - Atomic Emission Spectroscopy (ICP-AES) with a Thermo Fisher iCAP 6000 apparatus. In this paper, the quantity of zinc on the glass surface is systematically expressed in weight concentration per unit area $\left(\mu \mathrm{g} / \mathrm{cm}^{2}\right)$ of $\mathrm{Zn}^{2+}$ ions. With the spraying treatment, the concentration of $\mathrm{Zn}^{2+}$ ions on the glass surface was evaluated at $1.5 \pm 0.1 \mu \mathrm{g} / \mathrm{cm}^{2}$ for the highest concentration and at $0.1 \pm 0.03 \mu \mathrm{g} / \mathrm{cm}^{2}$ for the lowest concentration. They correspond respectively to the $\mathbf{Z P} \_\mathbf{1 . 5}$ and $\mathbf{Z P} \_\mathbf{0 . 1}$ treatment

This article is protected by copyright. All rights reserved. 
already described in the part I of this study. ${ }^{16}$ With the immersion treatment, the concentration of deposited $\mathrm{Zn}^{2+}$ was evaluated very close to the one with the spraying treatment of lowest concentration $\left(0.1 \pm 0.03 \mathrm{\mu g} / \mathrm{cm}^{2}\right)$, and is named $\mathbf{Z N} \_\mathbf{0 . 1}$. Details about these treatments are summarized in Table 1.

\subsection{Comparative study of the performances of the treatments against atmo- spheric alteration}

Accelerated atmospheric ageing tests were performed simultaneously on untreated and treated glass plates for comparative purposes, at $40{ }^{\circ} \mathrm{C}$ or $80^{\circ} \mathrm{C}, 85 \mathrm{RH} \%$, over various time periods - from one to several days - following the ageing protocol described in the part I of this study. ${ }^{16}$ To test the reproducibility, each sample was duplicated for each ageing experiments. These tests are noted V tests or VXd tests, where $\mathrm{X}$ is the total period in days (d) including the ramps (3 hours each). We emphasize that during these tests and until the time of their characterization, the contact of the glass surfaces with water in liquid state was strictly avoided.

Before and after a $\mathrm{V}$ test, the surfaces of the glass plates were characterized using optical microscopy. These observations were supplemented by electronic microscopy after the V tests with a Field Electron Gun-Scanning Electron Microscope (FEG-SEM, JEOL 7800F). Concomitant with the SEM observations, analyses by Energy Dispersive X-ray spectroscopy (EDX) at low accelerating voltage were performed with a Bruker QUANTAX 400 system for the characterization of the alteration products on glass surface. Chemical characterization of the alteration products was also undertaken by X-Ray Diffraction (XRD) with an X'Pert PRO PANalytical instrument using $\mathrm{Cu}-\mathrm{K}_{\alpha}$ radiation, and by micro-Raman spectroscopy with a Renishaw Invia instrument using a $532 \mathrm{~nm}$ solid-state laser as excitation light.

The hydration levels were compared for the different aged glass plates using Fourier-Transform InfraRed (FTIR) spectroscopy in transmission mode. Details about the operating conditions are given in the part I of this study ( ${ }^{16}$ - Supplemental Materials, section S 2.1).

This article is protected by copyright. All rights reserved. 


\subsection{Study of the $\mathrm{Zn}$ (II) speciation on glass surface}

$\mathrm{Zn}(\mathrm{II})$ speciation was studied for treated glass plates, before and after ageing tests, in order to follow its chemical evolution over time. The morphology and the nature of the precipitates on glass surface that formed consecutive to a zinc treatment was investigated by optical microscopy, by SEM-EDX, by XRD, and by micro-Raman spectroscopy (same operating conditions as those given above for the characterization of the alteration products).

To investigate the chemical environment of the $\mathrm{Zn}^{2+}$ ions which were potentially adsorbed on the glass surface or into the sub-surface, Grazing Incidence X-Ray Absorption Spectroscopy (GI-XAS) experiments were carried out at the $\mathrm{Zn}-\mathrm{K}$ edge $(9660.8 \mathrm{eV})$ at the synchrotron SOLEIL (beamline SAMBA). These measurements were performed at an incident angle close to $1^{\circ}$ (grazing incidence), in fluorescence mode, to probe only a thin surface layer. In addition to the treated glass plates, X-ray Absorption Near Edge Structure (XANES) spectra of seven $\mathrm{Zn}(\mathrm{II})$ reference compounds were collected in parallel in transmission mode. Among these compounds, six were solid standards, either commercial or synthetized in the laboratory, which could be present in the treated glass samples (having coordination number 4 or a mixture of 4 and 6 for the $\mathrm{Zn}(\mathrm{II})$ ), and one a liquid standard solution of $\mathrm{Zn}^{2+}$ (coordination number 6 ). These reference compounds are listed in Table 2, together with their respective synthesis method when relevant. One in particular was a glass sample (named glass $\mathbf{A}_{\mathbf{Z n}}$ ) specially prepared for this XANES study with composition similar to that of glass $\mathbf{A}$, and to which $2.6 \mathrm{wt} \% \mathrm{ZnO}$ was added in substitution of $\mathrm{SiO}_{2}$. $\mathrm{The}$ composition of the glass $\mathbf{A}_{\mathbf{Z n}}$ was checked by EDX and the purity of the other solid standards, in powder form, was checked by XRD. Powders were dispersed in cellulose and prepared in the form of pellets for the XANES experiments. XANES spectra were processed with the Demeter software (Athena interface). This study of the $\mathrm{Zn}$ (II) speciation on glass surface was supplemented by Tof-SIMS analysis of the glass plates, from the surface and in depth, to follow the progression of $\mathrm{Zn}$ (II) into the glass sub-surface (operating conditions given in Ref. ${ }^{19}$ and in the Supplemental Materials, section S 1.2 of the part I of this study $\left.{ }^{16}\right)$.

This article is protected by copyright. All rights reserved. 
Surface charges of glass powders, untreated or treated by immersion, were evaluated by electroacoustic measurements ${ }^{20}$ in order to assess the effect of the treatment on the electrostatic charge of the glass surface. These measurements were carried out using DT-300 equipment (Quantachrome/Dispersion Technology company), after calibration with colloidal silica $(28 \mathrm{~nm})$ dispersed in milliQ water (zeta potential $=-38 \mathrm{mV})$.

\section{RESULTS}

As described in the part I of this study, ${ }^{16}$ almost immediately after a spraying treatment, $\mathrm{Zn}^{2+}$ ions were shown to be uniformly sorbed on the glass surface at a surface concentration of about $0.1 \mathrm{\mu g} / \mathrm{cm}^{2}$ (about $9 \mathrm{at} / \mathrm{nm}^{2}$ ). The $\mathrm{Zn}^{2+}$ ions deposited in excess of this concentration were present as Zn-bearing precipitates, identified as $\mathrm{Zn}_{5}(\mathrm{OH})_{8}\left(\mathrm{NO}_{3}\right)_{2} \cdot 2 \mathrm{H}_{2} \mathrm{O}$.

The evaluation of the performances of the spraying treatment of highest concentration (ZP_1.5) has highlighted a positive effect on the reduction of the atmospheric alteration kinetics for the three glass replicas $\mathbf{A}$, SL and $\mathbf{P}$ (compositions given in the part I of this study ${ }^{16}$ ), under accelerated ageing conditions $\left(40^{\circ} \mathrm{C}\right.$ or $\left.80^{\circ} \mathrm{C}, 85 \mathrm{RH} \%\right)$, but not under the ambient atmosphere of the laboratory (2-years test).

Furthermore, when studying the influence of the treatment concentration with ageing tests at $80^{\circ} \mathrm{C}$, $85 \mathrm{RH} \%$, a positive effect was also observed for the treatment of lowest concentration (ZP_0.1), i.e. when only uniformly sorbed $\mathrm{Zn}^{2+}$ ions are present on glass surface before the ageing. It is worth noticing that the performances of the spraying treatment over time were found to be highly dependent on the amount of $\mathrm{Zn}^{2+}$ ions deposited on the glass surface: the more concentrated the treatment, the longer the protective action (section S2.2 in the Supplemental Materials of the Ref. ${ }^{16}$ ).

Considering these performances and the morphological and compositional change of the deposit with the ageing time as highlighted in the part I of this study, ${ }^{16}$ it is assumed that the deposited $\mathrm{Zn}^{2+}$ species

This article is protected by copyright. All rights reserved. 
have progressively reacted and transformed with time and temperature, and that the sorbed species in particular play a role in the protective action of zinc salts.

Results of the detailed study of this changing speciation, especially built on the comparison between the spraying treatment and the immersion treatment, are given in the following and discussed in the light of the respective performances of the treatments in order to draw up hypotheses regarding the protection mechanisms.

\subsection{Speciation of $\mathrm{Zn}(\mathrm{II})$ immediately after the deposition}

\subsubsection{Speciation for the $\mathrm{ZP}_{\_} 0.1$ and $\mathrm{ZN} \_0.1$ treatments}

To study specifically the speciation of the sorbed $\mathrm{Zn}^{2+}$ ions, we focus on the $\mathbf{Z P} \_\mathbf{0 . 1}$ and $\mathbf{Z N} \_\mathbf{0 . 1}$ treatments, for which no Zn-rich precipitates but only uniformly sorbed $\mathrm{Zn}^{2+}$ ions were identified on glass surface. Note that these two treatments could be distinguished from one another through the visual examination under microscope of the freshly treated glass surfaces: for the spraying treatment ZP_0.1, sub-micrometric crystals identified as $\mathrm{Na}$ and $\mathrm{K}$ nitrates were visible, while, on the contrary, no precipitate was observed for the immersion treatment ZN_0.1 (Fig. 1b) as compared with Fig. 1c). Zn elementary depth profiles of freshly treated glass plates, as obtained by Tof-SIMS analysis (purple and orange curves in Fig. 2a for $\mathbf{Z P} \_\mathbf{0 . 1}$ and $\mathbf{Z N} \_\mathbf{0 . 1}$ respectively) are characterized by a maximum intensity at the surface level that drops off very quickly in the first nanometers, then more progressively until the signal extinction around $40 \mathrm{~nm}$. The signal gathered after the first nanometers is likely due to the sputtering effect and could be an hint of the presence of small Zn-rich precipitates (around $40 \mathrm{~nm}$ thick). Thus, it appears that the sorbed $\mathrm{Zn}^{2+}$ were located mainly at the outer surface for both treatments. For the $\mathbf{Z P} \_\mathbf{0 . 1}$ treatment, the comparison of the $\mathrm{Zn}$ profiles before and after a short rinsing step (5 s) with milliQ water at ambient temperature, shows a significant decrease of the $\mathrm{Zn}^{2+}$ ionic intensity at the outer surface with the rinsing operation (purple curve compared to blue curve in Fig. 2a). The rinsing operation had thus removed a part of the $\mathrm{Zn}^{2+}$ ions, which reveals that they were only weakly sorbed

This article is protected by copyright. All rights reserved. 
on the glass surface. On the contrary, the Zn profile of a plate freshly treated by immersion in the hot $\mathrm{Zn}^{2+}$-bearing solution $\left(\mathbf{Z N} \_\mathbf{0 . 1}\right.$, orange curve), whose protocol included a short rinsing step after the immersion, was very close to that of $\mathbf{Z P} \_\mathbf{0 . 1}$ before any rinsing (purple curve), meaning that all the $\mathrm{Zn}^{2+}$ ions were strongly bound on glass surface after the immersion treatment $\mathbf{Z N} \_\mathbf{0 . 1}$.

We remind that in the immersion treatment, plates and powders were immersed in the $\mathrm{Zn}^{2+}$ aqueous solution at $60^{\circ} \mathrm{C}$. It is possible that this temperature contributed to fix the $\mathrm{Zn}^{2+}$ ions as chemisorbed species, while mostly physisorbed species were formed with the spraying treatment that was entirely carried out at ambient temperature.

Slightly dissimilar XANES signatures were obtained at the Zn K-edge for the freshly treated glass, depending on whether $\mathrm{Zn}^{2+}$ ions were deposited by spraying or by immersion, as depicted in Fig. 3. As evidenced by the qualitative comparison of the experimental XANES spectra of the reference compounds (Fig. 4a), the X-ray absorption signal at the Zn K-edge is influenced by the composition and the structure of the $\mathrm{Zn}^{2+}$ bearing phase. The peak position at the edge appears dependent on the coordination of $\mathrm{Zn}^{2+}$ ions. ${ }^{21}$ For instance, when $\mathrm{Zn}^{2+}$ ions are 4-fold coordinated, there is a shoulder or a low-intensity peak at about $9665 \mathrm{eV}$, next to another low-intensity peak located at about $9669 \mathrm{eV}$. When $\mathrm{Zn}^{2+}$ ions exist in a mixed 4-6 coordination, the first peak is slightly shifted (2-3 eV) to higher energy and gets closer to the second one, which peaks at about $9668 \mathrm{eV}$. In pure 6 -fold coordination as in the aqua complex, there is a single high-intensity peak at $9668 \mathrm{eV}$. For the $\mathbf{Z P} \_\mathbf{0 . 1}$ treatment, a shoulder around $9665 \mathrm{eV}$ was distinguished in addition to the main peak at $9668 \mathrm{eV}$, while for the $\mathbf{Z N} \_\mathbf{0 . 1}$ treatment the first $\mathrm{Zn}$ K-edge peak was clearly at $9665 \mathrm{eV}$ accompanied by a peak of similar intensity at $9669 \mathrm{eV}$. Moreover, the first EXAFS oscillation, located at about $9715 \mathrm{eV}$, is slightly shifted to higher energy in the ZN_ $\mathbf{0 . 1}$ sample with respect to the $\mathbf{Z P} \_\mathbf{0 . 1}$ (see the EXAFS domain in Fig. 3). As this oscillation mainly accounts for $\mathrm{Zn}-\mathrm{O}$ first neighbours correlation, this high-energy shift indicates shorter mean $\mathrm{Zn}-\mathrm{O}$ distances in the ZN_0.1 sample. Both features (XANES peaks and first EXAFS oscillation) point out a change in average coordination state: for the treatment by immersion $\left(\mathbf{Z N} \_\mathbf{0 . 1}\right) \mathrm{Zn}^{2+}$ are essentially 4-fold

This article is protected by copyright. All rights reserved. 
coordinated, while for the spraying treatment there is probably a mixture of 4- and 6-fold coordination. We emphasize that for these two treatments, no satisfactory simulation of their spectra could be obtained by linear combination of the reference compounds, demonstrating that the environment of these $\mathrm{Zn}^{2+}$ ions uniformly sorbed at the surface is specific and can not be strictly confused with zinc hydroxide or zinc hydroxide nitrate precipitates, or a glass environment.

The modification of the surface charges with the immersion treatment $\mathbf{Z N} \_\mathbf{0 . 1}$ was studied by the mean of electroacoustic measurements. For these measurements, calibrated glass powders, untreated or treated by immersion, were dispersed in an electrolyte at $\mathrm{pH} 10.3\left([\mathrm{KCl}]=10^{-2} \mathrm{M}\right.$ for ionic force control). At this $\mathrm{pH}$, the untreated glass surface was strongly charged $(-23.8 \mathrm{mV}$, Table 3$)$ and the treated glass had a considerably less negative charge $(-3.9 \mathrm{mV}$, Table 3$)$. Considering that the zero charge point of $\mathrm{ZnO}$ is relatively high (between 8 and $10^{22}$ ), these results indicate that the surface chemistry of the treated glass is dominated by the $\mathrm{ZnOH}$ bonds of sorbed species. Furthermore, successive acidification of the powder suspensions with $\mathrm{HCl}$ caused a decrease of the surface charge for the untreated glass $(-6.8 \mathrm{mV}$ at $\mathrm{pH} 5$, Table 3), as expected for a silicate glass. For the treated one, the surface charge decreased close to 0 at $\mathrm{pH} 8$ (Table 3 ) - and then became more negative, consistently with the desorption of $\mathrm{Zn}^{2+}$ ions below $\mathrm{pH}$ 7. This near cancellation of the surface charge at a $\mathrm{pH}$ close to neutrality in the treated glass indicates that the surface has become less hydrophilic with the treatment. Indeed, an amphoteric charged surface has an additional surface energy term due to the electrostatic potential of the surface and to the electrostatic interaction with the diffuse double layer. At the point of zero charge, the surface hydrophilic property is at its minimum. ${ }^{23}$

\subsubsection{Speciation for the spraying treatment of highest concentration $\left(\mathrm{ZP} \_\right.$1.5)}

For the spraying treatment of highest concentration $\mathbf{Z P} \_\mathbf{1 . 5}$, the largest crystals that formed immediately after the treatment were identified as zinc hydroxide nitrate $\mathrm{Zn}_{5}(\mathrm{OH})_{8}\left(\mathrm{NO}_{3}\right)_{2} \cdot 2 \mathrm{H}_{2} \mathrm{O}$ and the sub-micrometric ones as $\mathrm{Na}$ and $\mathrm{K}$ nitrates (Fig. 1a). The only other Zn-bearing species identified at

This article is protected by copyright. All rights reserved. 
the surface of these treated glass plates were the sorbed $\mathrm{Zn}^{2+}$ ions outside the precipitates, at a concentration level of about $0.1 \mathrm{\mu g} / \mathrm{cm}^{2}$ (part I of this study ${ }^{16}$ ). By analogy with the spraying treatment of lowest concentration $\mathbf{Z P} \_\mathbf{0 . 1}$, at least a fraction of these sorbed $\mathrm{Zn}^{2+}$ ions were probably weakly bound on the glass surface (physisorption). The total concentration of $\mathrm{Zn}^{2+}$ ions deposited on the glass surface being close to $1.5 \mathrm{\mu g} / \mathrm{cm}^{2}$, the $\mathrm{Zn}^{2+}$ ions present under the form of precipitates of zinc hydroxide nitrate were in large excess as compared with the $\mathrm{Zn}^{2+}$ ions sorbed on glass surface. Therefore, as expected, the XANES signature of the freshly treated glass plate is very similar to the one of the reference compound $\mathrm{Zn}_{5}(\mathrm{OH})_{8}\left(\mathrm{NO}_{3}\right)_{2} \cdot 2 \mathrm{H}_{2} \mathrm{O}$ (pink solid line as compared to the turquoise solid line in Fig. 4b).

\subsection{Evolution of the distribution and speciation of $\mathrm{Zn}(\mathrm{II})$ during the ageing and relative contribution to the protection}

\subsubsection{Comparison of the effects of the treatments}

As described in a previous study, a $\mathrm{V}$ test of the glass $\mathbf{A}$ at $80{ }^{\circ} \mathrm{C}, 85 \mathrm{RH} \%$, lasting 1 day, produces a hydrated layer that retains the alkalis. When the aged glass plates are removed from the climatic chamber and left in the laboratory atmosphere, alkali carbonate salts form on glass surface and grow progressively with time, as a symptomatic manifestation of the glass hydration. ${ }^{17}$ Their dendritic morphology is shown on the optical image in Fig. 5a, taken several weeks after the removal of the glass plate from the climatic chamber.

For both the spraying treatment of lowest concentration $\mathbf{Z P} \_\mathbf{0 . 1}$ and the immersion treatment $\mathbf{Z N} \_\mathbf{0 . 1}$, we observed the same behaviour, ie formation and growth of $\mathrm{Na}$ carbonates when the samples were left in ambient atmosphere after the ageing at $80^{\circ} \mathrm{C}$ and $85 \mathrm{RH} \%$. However, compared to the untreated glass, these dendritic carbonates appeared significantly less numerous on the surface of the treated glass plates (Fig. 5c and 5d as compared with Fig. 5a). On the contrary, for the spraying treatment of highest concentration (ZP_1.5), the morphology of precipitation on glass surface remained stable in ambient atmosphere after the ageing. The surface state appeared in fact little changed with the ageing at least

This article is protected by copyright. All rights reserved. 
in terms of morphology of the precipitates (Fig. 5b as compared with Fig. 1a). In particular, no Nacarbonates could be detected on the glass surface. Before the ageing, all the precipitates bearing $\mathrm{Zn}$ were identified as zinc hydroxide nitrate $\mathrm{Zn}_{5}(\mathrm{OH})_{8}\left(\mathrm{NO}_{3}\right)_{2} \cdot 2 \mathrm{H}_{2} \mathrm{O}$. Together with $\mathrm{Na}$ and $\mathrm{K}$ nitrates, they were the only crystals present on the surface. After the ageing, Na and K nitrates were still present. The Zn-bearing precipitates had only slightly transformed morphologically, and their composition and nature had changed, because hydroxyde nitrate could be identified only in a few cases by Raman spectroscopy. The decrease of the surface density of Na-carbonates with the spraying treatment is directly linked to the reduction of the hydrated layer thickness. This reduction was more pronounced with the $\mathbf{Z P} \_\mathbf{1 . 5}$ treatment than with the $\mathbf{Z P} \_\mathbf{0 . 1}$ treatment (see part I of this study ${ }^{16}$ ). For the $\mathbf{Z N} \_\mathbf{0 . 1}$ treatment as well, a significant reduction of the global hydration level was highlighted by FTIR experiments in transmission mode in the region associated to the absorbance of the -OH groups at $3700-2500 \mathrm{~cm}^{-1}$ after an ageing at $80^{\circ} \mathrm{C}, 85 \mathrm{RH} \%$, for a 1 day period (orange curve as compared to the red curve associated to the untreated glass in Fig. 6). It is worth mentioning that in these conditions (1 day of ageing), the reduction of the global hydration level was similar for the $\mathbf{Z N} \_\mathbf{0 . 1}$ treatment and the $\mathbf{Z P} \_\mathbf{1 . 5}$ treatment (15 times more concentrated in $\mathrm{Zn}^{2+}$ ions compared to $\mathbf{Z N} \_\mathbf{0 . 1}$ ) (orange and green curves in Fig. 6). Moreover, for a same concentration of deposited $\mathrm{Zn}^{2+}$ ions on glass surface, the protection given by the immersion treatment $\mathbf{Z N} \_\mathbf{0 . 1}$ was better than that of the spraying treatment $\mathbf{Z P} \_\mathbf{0 . 1}$ (orange and purple curves in Fig. 6), which suggests that the $\mathrm{Zn}^{2+}$ ions chemisorbed on glass surface would lead to a better protection than the physisorbed ones. However, for longer ageing periods at $80^{\circ} \mathrm{C}$, $85 \mathrm{RH} \%$, the performances of the treatment by immersion were clearly reduced, both in terms of hydrated layer thicknesses and surfaces states, when compared with the spraying treatment that is 15 times more concentrated. 


\subsubsection{Evolution of the speciations}

The evolution of the speciation of $\mathrm{Zn}^{2+}$ ions on the glass surface was followed by comparing the XANES spectra of the freshly treated glass plates described above with their respective equivalents after an ageing at $80^{\circ} \mathrm{C}, 85 \mathrm{RH} \%$, for 1 day or at $40^{\circ} \mathrm{C}, 85 \mathrm{RH} \%$, for 10 days.

For the ZN_0.1 treatment (orange curves in Fig. 4b), the evolution of the XANES spectrum (associated to the $\mathrm{Zn}^{2+}$ ions chemisorbed on glass surface) was more pronounced with an ageing at $80^{\circ} \mathrm{C}$ for 1 day than at $40{ }^{\circ} \mathrm{C}$ for 10 days. In the former spectrum, two resolved peaks are well visible, the first at around $9665 \mathrm{eV}$ and the second at around $9669 \mathrm{eV}$. Interestingly, this spectral signature is close to that of the reference glass $\mathbf{A}_{\mathbf{Z n}}$ (burgundy curve in Fig. 4b). By using a linear combination of freshly treated $\mathbf{Z N}$ _. $\mathbf{0 . 1}$ and glass $\mathbf{A}_{\mathbf{Z n}}$ reference spectra, a satisfactory spectrum simulation was obtained, with a contribution of the glass $\mathbf{A}_{\mathbf{Z n}}$ larger than $80 \%$ (Fig. 7a). Therefore, according to the XANES signatures, the environment of $\mathrm{Zn}^{2+}$ ions after 1 day of ageing at $80^{\circ} \mathrm{C}, 85 \mathrm{RH} \%$, resembles the environment of $\mathrm{Zn}^{2+}$ ions inserted in a glass silicate network. This suggests that the $\mathrm{V}$ test at $80{ }^{\circ} \mathrm{C}, 85 \mathrm{RH} \%$, caused diffusion of $\mathrm{Zn}^{2+}$ ions, in one day, into the glass near-surface, probably by insertion into the silicate network, as depicted in Fig. 8. This assumption is corroborated by Tof-SIMS analysis of the ZN_ 0.1-treated and aged glass plate: Zn-signal has clearly dropped at the outer surface and extended in depth with the ageing (orange curve on Fig. 2b as compared to the orange curve on Fig. 2a).

For the ZP_0.1 treatment (purple curves in Fig. 4b), a similar evolution of the XANES spectrum (probably associated to a mixture of $\mathrm{Zn}^{2+}$ ions chemisorbed and physisorbed on glass surface) was observed with the ageing at $80^{\circ} \mathrm{C}, 85 \mathrm{RH} \%$ for 1 day (Fig. $7 \mathrm{~b}$ ): all the $\mathrm{Zn}^{2+}$ ions progressively diffused into the near-surface and bound to the silicate network during ageing. From Tof-SIMS analysis, the Zn signal has indeed dropped at the outer surface with the ageing for the $\mathbf{Z P} \_\mathbf{0 . 1}$ treatment (purple curve on Fig. 2b as compared to the purple curve on Fig. 2a). However, the Zn in-depth diffusion has less advanced for the $\mathbf{Z P} \_\mathbf{0 . 1}$ treatment than for the $\mathbf{Z N}$ _0.1 treatment (Fig. 2b). On the other hand, the spectrum of the $\mathbf{Z P} \_\mathbf{0 . 1}$ treated sample aged at $40{ }^{\circ} \mathrm{C}, 85 \mathrm{RH} \%$ for 10 days stayed almost identical to the one of the

This article is protected by copyright. All rights reserved. 
freshly treated sample.

Note that with the ZP_1.5 treatment (pink curves in Fig. 4b), the XANES spectral signature of the aged glass plate at $40^{\circ} \mathrm{C}$ is very similar to that of the freshly treated glass plate and of the reference compound zinc hydroxide nitrate. After a $\mathrm{V}$ test at $80^{\circ} \mathrm{C}, 85 \mathrm{RH} \%$, for 1 day, a shoulder at around $9665 \mathrm{eV}$ appeared on the absorption edge, which suggests a contribution of the $\mathrm{Zn}^{2+}$ ions bound to the silicate network, although no satisfactory simulation could be obtained from the reference compounds.

\section{DISCUSSION}

\subsection{Speciation of $\mathrm{Zn}$ (II) immediately after the treatment and its change with}

\section{the ageing}

From these results, it appears that there is a threshold concentration value, close to $0.1 \mathrm{\mu g} / \mathrm{cm}^{2}$, below which the $\mathrm{Zn}^{2+}$ ions are uniformly sorbed on the glass surface. It is noticeable that this concentration threshold is the same for both the spraying and the immersion treatments. Note that a similar concentration threshold was also found for both treatments applied on a microscope slide (soda-lime silicate glass). The deposited $\mathrm{Zn}(\mathrm{II})$ surface concentration corresponds to about $9 \mathrm{at} / \mathrm{nm}^{2}$ (between about 6 and $\left.12 \mathrm{at} / \mathrm{nm}^{2}\right)$. This value is high if we compare with the surface density of $\mathrm{Si}-\mathrm{OH}$ groups on amorphous silica, which is about $5 \mathrm{at} / \mathrm{nm}^{2}$. Langmuir adsorption isotherms of $\mathrm{Zn}^{2+}$ measured on colloidal silica at $\mathrm{pH} 9.4$ (ie with maximal ionization of the silica surface) show that the maximum amount of adsorbed $\mathrm{Zn}^{2+}$ is less than $2 \mathrm{at} / \mathrm{nm}^{2}$ on amorphous silica. ${ }^{24}$ Therefore, one has to consider that a majority of $\mathrm{Zn}^{2+}$ ions are probably not directly adsorbed on the surface but rather form a few sorbed layers. The surface precipitation of an amorphous $\mathrm{Zn}(\mathrm{OH})_{2}$ phase has been suggested at moderate $\mathrm{pH}$ and high surface coverage conditions $(\Gamma)$ on silica $\left(\mathrm{pH}=7.5\right.$ and $\Gamma=2 \mu \mathrm{mol} \mathrm{m}{ }^{-2}$ corresponding to about $\left.1.2 \mathrm{at} / \mathrm{nm}^{2}\right){ }^{25}$ It is then probable that surface precipitation has occurred on top of the adsorbed layer. To serve as a reference value, in orthorhombic $\mathrm{Zn}(\mathrm{OH})_{2}$ the volume of a zinc ion is $0.054 \mathrm{~nm}$, therefore $10 \mathrm{Zn}^{2+}$ ions per

This article is protected by copyright. All rights reserved. 
$\mathrm{nm}^{2}$ correspond to a $\mathrm{Zn}(\mathrm{OH})_{2}$ thickness of about $0.54 \mathrm{~nm}$, probably a little more for amorphous $\mathrm{Zn}(\mathrm{OH})_{2}$. As a matter of fact, the formation of numerous alkali nitrate salts spread out on glass surface treated by ZP_0.1 indicates that at least a fraction of $\mathrm{Zn}^{2+}$ ions may have precipitated with $\mathrm{OH}^{-}$ions according to the formal reaction:

$$
\mathrm{Zn}^{2+}+2 \mathrm{NO}_{3}^{-}+2 \equiv \mathrm{Si}-\mathrm{O}^{-} \mathrm{Na}^{+}+2 \mathrm{H}_{2} \mathrm{O} \longrightarrow 2 \equiv \mathrm{Si}-\mathrm{OH}+\mathrm{Zn}(\mathrm{OH})_{2}+2 \mathrm{NaNO}_{3}
$$

This reaction occurs in the water film adsorbed on glass surface in equilibrium with the relative humidity. At $85 \mathrm{RH} \%$ on silica glass, the water film is about $2 \mathrm{~nm}$ thick, bearing about 6 layers of water molecules. ${ }^{26}$ On an alkali silicate glass, the acid-base reaction with (or hydrolysis of) surface $\mathrm{Si}-\mathrm{O}^{-} \mathrm{Na}^{+}$sites releases $\mathrm{Na}^{+}$and $\mathrm{OH}^{-}$in the water film, which is probably thicker because of the solvatation of these ions. Such $\mathrm{NaOH}$-rich water films were observed on alkali-rich glass compositions of the cultural heritage aged in neutral $\mathrm{N}_{2}$ atmosphere. ${ }^{27}$ Thus, reaction (1) can also be viewed as the result of acid-base reaction between the water film and the glass surface, followed by $\mathrm{Zn}(\mathrm{OH})_{2}$ precipitation. An alternative mechanism is surface acidification due to $\mathrm{Zn}(\mathrm{OH})_{2}$ precipitation that is followed by $\mathrm{Na}^{+} / \mathrm{H}^{+}$ionic exchange in the sub-surface. Which of the acid-base reaction, or the $\mathrm{Zn}(\mathrm{OH})_{2}$ precipitation would be the first can not be answered in this work.

On the other hand, as outlined, the substrates are not amorphous silica but alkali-rich silicate glasses. It is possible that the surface density of adsorption sites is higher than for amorphous silica, because of the higher packing density of oxygens in alkali modified silicate networks. The above-mentioned surface precipitation may thus be minimized with respect to the surface adsorption that is discussed thereafter. This is notably suggested by the XANES spectra of the treated samples, which do not resemble that of the $\mathrm{Zn}(\mathrm{OH})_{2}$ reference (an amorphous precipitate) as shown in Fig. 3.

Although the surface concentration of deposited $\mathrm{Zn}^{2+}$ ions is the same, there are important differences of speciation between both treatments, which are likely related to the surface adsorbed layer. In the $\mathbf{Z P} \_\mathbf{0 . 1}$ treatment, a part of the zinc ions are weakly bound (as demonstrated by the rinsing experiment) and the

This article is protected by copyright. All rights reserved. 
XANES signature suggests a mixture of 4 - and 6 -fold coordination. We propose that the weakly bound $\mathrm{Zn}^{2+}$ ions form layers of hydrated or hydrolyzed species (as $\left.\mathrm{Zn}(\mathrm{OH})_{2}\right)$ physisorbed on their bottom layer, ie they are bound by electrostatic and dipolar interactions only to the glass surface. These physisorbed species may comprise 6 -fold coordinated species because 6 -fold coordination is common in zinc hydroxide phases (see table 1 in Ref. ${ }^{28}$ ). On the contrary, in the $\mathbf{Z N} \_\mathbf{0 . 1}$ treatment, the nature of the surface adsorbed layer is chemisorption only (with possibly some zinc hydroxide surface precipitation on top of it). The chemisorption implies the removal of at least one water molecule from the $\mathrm{Zn}^{2+}$ solvatation sphere and its substitution by one $\mathrm{Si}-\mathrm{OH}$ surface group, forming inner-sphere $\mathrm{Zn}^{2+}$ complexes. According to the Zn-K edge XANES profile of the ZN_0.1 sample indicating 4-fold coordination, and to the literature, ${ }^{24,25}$ we propose a bidentate mononuclear fourfold-coordinated complex as product of the formal chemisorption reaction:

$$
\mathrm{Zn}^{2+}+2 \mathrm{NO}_{3}^{-}+2 \equiv \mathrm{Si}-\mathrm{OH}+2 \mathrm{H}_{2} \mathrm{O} \longrightarrow(\equiv \mathrm{Si}-\mathrm{O})_{2} \mathrm{Zn}\left(\mathrm{H}_{2} \mathrm{O}\right)_{2}+2 \mathrm{HNO}_{3}
$$

Again, we can consider that $\mathrm{Si}-\mathrm{O}^{-} \mathrm{Na}^{+}$surface sites are hydrolyzed or that the acidification is followed by $\mathrm{Na}^{+} / \mathrm{H}^{+}$ionic-exchange, or (equivalently) that $\mathrm{Si}-\mathrm{O}^{-} \mathrm{Na}^{+}$surface sites directly take part to the reaction

$$
\mathrm{Zn}^{2+}+2 \mathrm{NO}_{3}^{-}+2=\mathrm{Si}-\mathrm{O}^{-} \mathrm{Na}^{+}+2 \mathrm{H}_{2} \mathrm{O} \longrightarrow(=\mathrm{Si}-\mathrm{O})_{2} \mathrm{Zn}\left(\mathrm{H}_{2} \mathrm{O}\right)_{2}+2 \mathrm{NaNO}_{3}
$$

The chemisorption also produces alkali nitrate salts. The reactions (2) and (3) are written as guides only, because our data do not allow to determine the exact coordination of the inner-sphere complex. It is well emphasized in the literature that $\mathrm{Zn}^{2+}$ ions show a great variability of inner-sphere complex structures according to the substrate, coverage ratio, temperature and $\mathrm{pH} .{ }^{25}$

At last, when the concentration of deposited $\mathrm{Zn}^{2+}$ ions exceeds $0.1 \mathrm{\mu g} / \mathrm{cm}^{2}$, the excess $\mathrm{Zn}^{2+}$ ions precipitate with $\mathrm{OH}^{-}$ions forming zinc hydroxide nitrate:

This article is protected by copyright. All rights reserved. 


$$
5 \mathrm{Zn}^{2+}+10 \mathrm{NO}_{3}^{-}+10 \mathrm{H}_{2} \mathrm{O} \longrightarrow \mathrm{Zn}_{5}(\mathrm{OH})_{8}\left(\mathrm{NO}_{3}\right)_{2} \cdot 2 \mathrm{H}_{2} \mathrm{O}+8 \mathrm{HNO}_{3}
$$

Again, it is expected that the hydrolysis of the $\mathrm{Si}-\mathrm{O}^{-} \mathrm{Na}^{+}$surface sites take part to the reaction or that the acidification is followed by $\mathrm{Na}^{+} / \mathrm{H}^{+}$ionic-exchange, which can be formally written as :

$$
5 \mathrm{Zn}^{2+}+10 \mathrm{NO}_{3}^{-}+8 \equiv \mathrm{Si}-\mathrm{O}^{-} \mathrm{Na}^{+}+10 \mathrm{H}_{2} \mathrm{O} \longrightarrow 8 \equiv \mathrm{Si}-\mathrm{OH}+\mathrm{Zn}_{5}(\mathrm{OH})_{8}\left(\mathrm{NO}_{3}\right)_{2} \cdot 2 \mathrm{H}_{2} \mathrm{O}+8 \mathrm{NaNO}_{3}
$$

To check if $\mathrm{Si}-\mathrm{O}^{-} \mathrm{Na}^{+}$surface sites are directly involved in this precipitation reaction, we applied the ZP_1.5 treatment on a surface of pure vitreous silica. Although this glass does not bear any $\mathrm{Si}-\mathrm{O}^{-} \mathrm{Na}^{+}$ site, we observed the formation of zinc hydroxide nitrate. This suggests that $\mathrm{Zn}^{2+}$ ions can precipitate "first", with the $\mathrm{OH}^{-}$ions generated by the negative $\mathrm{Si}-\mathrm{O}^{-}$sites of the surface.

To summarize, $\mathrm{Zn}^{2+}$ ions deposited on the glass surface distribute into three components : the chemisorbed species, the physisorbed species, and the hydroxide or nitrate hydroxide precipitates. The chemisorbed species are more numerous and dominant with the treatment by immersion in hot water. This is not surprising, as most of the divalent cation chemisorption phenomena are endothermic, ${ }^{29}$ indicating that the chemisorption is driven by the entropy increase due to the release of molecular water, rather than to enthalpic effects. This has been demonstrated for $\mathrm{Zn}^{2+}$ adsorption onto colloidal silica ${ }^{18}$ and ferrihydrite. $^{30}$

With the ageing at $80^{\circ} \mathrm{C}$ and $85 \mathrm{RH} \%$, the physisorbed and precipitated species are converted into chemisorbed species, as shown by the evolution of the Zn K-edge XANES spectra. This is consistent with the endothermic character of the chemisorption. Also, it reveals that the precipitated layers can interact with the surface, probably because the $\mathrm{Zn}(\mathrm{II})$ diffuses within the glass at this temperature. This diffusion is clearly demonstrated in our study by the TOF-SIMS depth profiles in Fig. 2b and by the XANES spectrum of the ZN_0.1 treated sample after the ageing in Fig. 4b that closely resembles the glass reference spectrum. Such a diffusion within the glass had also been demonstrated by TOF-SIMS

This article is protected by copyright. All rights reserved. 
on borosilicate glass immersed in $\mathrm{ZnSO}_{4}$ solution at $60{ }^{\circ} \mathrm{C} .{ }^{10}$ Moreover, $\mathrm{Zn}(\mathrm{II})$ inward diffusion might explain why the surface density of the $\mathrm{Zn}_{5} \mathrm{OH}_{8}\left(\mathrm{NO}_{3}\right)_{2} \cdot 2 \mathrm{H}_{2} \mathrm{O}$ precipitates is reduced with the ageing at $80^{\circ} \mathrm{C}$ for the high concentration $\mathbf{Z P} \_\mathbf{1 . 5}$ treatment. The precipitates can be viewed as "reservoirs" providing new $\mathrm{Zn}(\mathrm{II})$ as more and more of ions diffuse within the glass. This observation also indicates that the formation of a $\mathrm{Zn}(\mathrm{II})$-enriched silicate layer seems thermodynamically favored with respect to the zinc hydroxide phases, driving the inward $\mathrm{Zn}$ (II) diffusion. In the literature, formation of zinc silicate phases has been reported in various circumstances where a glass is attacked in $\mathrm{Zn}$ (II)-bearing solution $^{31,32}$ or a ZnO-bearing glass in water. ${ }^{11,33}$ One of these phases, when identified, is hemimorphite $\left(\mathrm{Zn}_{4} \mathrm{Si}_{2} \mathrm{O}_{7}(\mathrm{OH})_{2} \cdot \mathrm{H}_{2} \mathrm{O}\right)$ that is a highly insoluble phase. ${ }^{34}$

\subsection{Possible origins of the passivation induced by zinc salts}

Four hypotheses can be formulated to explain the protection due to zinc salt deposit on the glass surface:

i) There is a « buffering effect » stemming from the precipitation of $\mathrm{Zn}^{2+}$ with the $\mathrm{OH}^{-}$ions coming from the glass alteration process, ${ }^{32}$

ii) The zinc species chemisorbed on the surface and the one inserted near-surface form a passivating barrier, ${ }^{10}$

iii) The zinc species inserted in the glass near-surface make the surface less soluble (i.e. they stabilize the surface with respect to the dissolution products), ${ }^{35}$

iv) The neutralization of the surface charges by the zinc species chemisorbed on the surface makes it less hydrophilic. ${ }^{10,15,23}$

Following hypothesis (i), the deposit of $\mathrm{Zn}^{2+}$ ions would contribute to acidify the glass surface (by consuming the $\mathrm{OH}^{-}$ions or by $\mathrm{Na}^{+} / \mathrm{H}^{+}$exchange), maintaining a local $\mathrm{pH}$ value below 9 and thus slowing down the network hydrolysis. However, when the spraying treatment was applied on a pure

This article is protected by copyright. All rights reserved. 
vitreous silica surface, the formation of zinc hydroxide nitrate was also observed despite the lack of nonbridging oxygen atoms in the glass structure. This precipitation, which is almost immediate, is probably similar for glass $\mathbf{A}$ : it mostly neutralizes the negative charges on glass surface and not the $\mathrm{Si}-\mathrm{O}^{-} \mathrm{Na}^{+}$sites in the near-surface. Furthermore, if the $\mathrm{OH}^{-}$ions stemming from the reaction of $\mathrm{H}_{2} \mathrm{O}$ with $\mathrm{Si}-\mathrm{O}^{-} \mathrm{Na}^{+}$ sites were responsible for the $\mathrm{Zn}^{2+}$ precipitation, then the number of Zn-precipitates would increase with the hydration time, which is clearly not observed. Instead, the zinc precipitates appeared less numerous on the glass surface after the ageing tests. Thus, we assume that the contribution of hypothesis (i) to explain the protection effect of zinc ions is very limited, at least over time.

All remaining hypotheses imply the $\mathrm{Zn}(\mathrm{II})$ chemisorbed species and the $\mathrm{Zn}$ (II) inserted in the near surface. Comparing the performances of the $\mathbf{Z P} \_\mathbf{0 . 1}$ and $\mathbf{Z N} \_\mathbf{0 . 1}$ treatments clearly indicated that these species were the most efficient for the protection. The protection was extended over time for the ZP_1.5 treatment certainly because $\mathrm{Zn}^{2+}$ ions in the hydroxide phases could get progressively converted into chemisorbed species. This conversion occurred under thermal activation.

The high affinity of silicate substrate for the Zn(II) ions has been many times noticed in the literature. It manifests either in the rapid kinetics of the $\mathrm{Zn}$ (II) adsorption, ${ }^{25}$ or in the high $\mathrm{Zn}$ (II) uptake at low Zn(II) concentration in adsorption isotherms, ${ }^{24}$ or by the fact that the $\mathrm{Zn}(\mathrm{II})$ adsorption strongly increases the surface ionization (release of $\mathrm{H}^{+}$into the solution). The $\frac{\mathrm{H}^{+}}{\mathrm{Zn}^{2+}}$ ratio is more than 2, and can reach 3 meaning that the surface capacity increases with the $\mathrm{Zn}(\mathrm{II})$ adsorption. ${ }^{18,24}$ Phan et al. conclude from their study that "Zn ions bind much more strongly and closer to the silanol group than $\mathrm{Na}^{+}$ions". To our opinion, this particularly high affinity has a structural origin. The $\mathrm{Zn}^{2+}$ ions are small with a high effective nuclear charge and sp valence orbitals, which favors the 4-fold coordination and make them compatible with the network forming position in silicate glasses. ${ }^{36}$ The ability of $\mathrm{Zn}$ (II) to diffuse within the glass seems to confirm that.

Chemisorbed and near-surface species contribute to form a Zn-enriched surface and near-surface layer that probably acts as a diffusion barrier for water and/or for dissolved species. This diffusion barrier slows

This article is protected by copyright. All rights reserved. 
down the hydration without stopping it, and can prevent soluble species to be released into solution. ${ }^{10}$ In the present study, we observed that $\mathrm{Ca}^{2+}$ ions were not extracted from the treated glass during alteration, whereas they were extracted and precipitated as calcite on the surface of the untreated glass (see part I of this study $\left.{ }^{16}\right)$. Indeed, the divalent $\mathrm{Ca}^{2+}$ and $\mathrm{Zn}^{2+}$ ions may take the same diffusion paths into the network.

On the basis of water uptake measurements, Nunes de Carvalho et al. suggested that the sorption of $\mathrm{Zn}(\mathrm{II})$ makes the glass surface less hydrophilic. ${ }^{15}$ The surface charge of the ZN_0.1 treated glass has indeed dropped in the neutral to basic $\mathrm{pH}$ range, which certainly diminishes the number of water molecules able to adsorb and diffuse at the surface.

At last, the $\mathrm{Zn}(\mathrm{II})$ sorption could contribute to the thermodynamic stabilization of the surface and subsurface. The introduction of $\mathrm{ZnO}$ in silicate glasses increases their chemical durability in immersion conditions ${ }^{14,33}$ and their critical pH of dissolution. ${ }^{35}$ This is corroborated by the very low solubility of some Zn-hydroxy-silicate phases such as hemimorphite.

\section{CONCLUSION}

In this article, the speciation and localization of the $\mathrm{Zn}^{2+}$ ions deposited on the glass surface by a spraying treatment, or by an immersion treatment at $60^{\circ} \mathrm{C}$, have been investigated by grazing-incidence $\mathrm{Zn} \mathrm{K}$-edge XANES spectroscopy and by TOF-SIMS. In the spraying treatment, the $\mathrm{Zn}^{2+}$ ions are distributed among chemisorbed species, physisorbed species and precipitated hydroxide phases $\left(\mathrm{Zn}_{5}(\mathrm{OH})_{8}\left(\mathrm{NO}_{3}\right)_{2} \cdot 2 \mathrm{H}_{2} \mathrm{O}\right.$ and possibly $\left.\mathrm{Zn}(\mathrm{OH})_{2}\right)$. By thermal activation, the physisorbed and hydroxide species can convert into chemisorbed species, and $\mathrm{Zn}^{2+}$ ions diffuse into the glass.

By comparing the performances of the treatments, it appears that the most efficient $\mathrm{Zn}(\mathrm{II})$ species for glass protection are the $\mathrm{Zn}(\mathrm{II})$ chemisorbed at the surface and those inserted in the glass structure in the near-surface. The hypotheses to explain the evolution of the performance of the $\mathrm{Zn}$ treatment are 
the insolubility and diffusion barrier properties of the Zn-rich silicate surface layer, and the reduction of the hydrophilic character of the surface. Because these efficient species are formed by thermal activation, the protective action of zinc salts manifests at high temperature $\left(80^{\circ} \mathrm{C}\right.$ and to a lesser extent $\left.40^{\circ} \mathrm{C}\right)$, explaining that no benefit of the spraying treatment was observed at ambient temperature after 2 years of experiments. Thus, in the perspective of applying this kind of treatment on objects of the cultural heritage, a moderate heating step seems necessary during or after the treatment. Further experiments aiming at evaluating the efficacy of a such treatment protocol againt the atmospheric alteration of glass under ambient temperature should be carried out. It seems reasonnable to expect an appreciable efficacy in these conditions of use considering the protocol of the zinc salts treatment in the glass industry.

\section{Acknowledgements}

The authors gratefully thank PSL University for the funding of this work, Marie-Hélène Chopinet, Sophie Papin and Kamila Plevacova (Saint-Gobain Recherche, France) for the glass fabrication. For their skillful assistance during experimental analysis, the authors also thank Emiliano Fonda (beamline SAMBA, synchrotron SOLEIL) for XAS measurements.Région Ile-de-France is acknowledged for the partial funding of the Tof-SIMS equipment.

\section{References}

${ }^{1}$ Rullier R. Procédé de Traitement des Surfaces de Verre. Patent FR 2269500A1; 1975.

${ }^{2}$ Lewchuk R, Moser F. Treatment of glass surfaces. Patent CA 770571 A; 1967.

${ }^{3}$ Chopinet MH, Lehuédé P. Les problèmes d'altération rencontrés sur des verres industriels. Verre. 2010;16:20-27.

This article is protected by copyright. All rights reserved. 
${ }^{4}$ Emonds M, Villari V. Protective coating of float glass by liquid anti- corrosion systems. Glass Performance Days. 2009:649-653. Available from: www.gpd.fi.

${ }^{5}$ Berger PS, Song BX, Schwartz JR, Corkery RW. Zinc corrosion protection agents for treating glassware surfaces. Patent US 7094740 B2; 2006.

${ }^{6}$ Caravajal GS. Rinse additive compositions providing glassware protection. Patent EP 0383480A1; 1990.

${ }^{7}$ Keyes G, Seaman B, Kassen J. Liquid automatic dishwashing composition with glass ware protection. Patent US 6448210; 2002.

${ }^{8}$ Eiting T, Mussman N, Bastigkeit T, Benda K, Kessler A, Maisey C, et al.. Dishwashing detergents with improved protection of decoration. Patent WO 2012175292 A1; 2012.

${ }^{9}$ Hahn K. Protection of glassware in the automatic dishwashing process - a detergent manufacturer's insight and experiences. In: Biron I, Alloteau F, Lehuédé P, Majérus O, Caurant D, editors. Glass Atmospheric Alteration - Cultural Heritage, industrial and Nuclear Glasses. Paris: Hermann; 2019. p. $209-214$.

10 Tait JC, Jensen CD. The effect of Zn(II) ion adsorption on the durability of sodium borosilicate glasses. J Non-Cryst Solids. 1982;49:363-377.

${ }^{11}$ Lewis RA, Myhra S, Segall RL, Smart RSC, Turner PS. The surface layer formed on zinc-containing glass during aqueous attack. J Colloid Interf Sci. 1982;53:299-313.

${ }^{12}$ Oka Y, Tomozawa M. Effect of alkaline earth ion as an inhibitor to alkaline attack on silica glass. J Non-Cryst Solids. 1980;42(1-3):535-543.

${ }^{13}$ Reiß S, Urban S, Jacob K, Krischok S, Rädlein E. Investigation of the influence of a commercial glass protector on float glass surfaces by X-ray photoelectron spectroscopy. Phys Chem Glasses-B. 2017;58:99-108. 
${ }^{14}$ Della Mea G, Gasparotto A, Bettinelli M, Montenero A, Scaglioni R. Chemical durability of zinccontaining glasses. J Non-Cryst Solids. 1986;84:443-451.

${ }^{15}$ Nunes de Carvalho J, Cleaver JAS, Kirkby NF, Holmes PA. An experimental study of the effect of zinc treatment on float glass. Glass Technol-Part A. 2014;55(1):14-22.

${ }^{16}$ Alloteau F, Majérus O, Valbi V, Biron I, Lehuédé P, Caurant D, et al. Efficacy of zinc salts to protect glass against atmospheric alteration. Part I: Effects of a spraying treatment. submitted to J Am Ceram Soc.

${ }^{17}$ Alloteau F, Lehuédé P, Majérus O, Biron I, Dervanian A, Charpentier T, et al. New insight into atmospheric alteration of alkali-lime silicate glasses. Corros Sci. 2017;122:12-25.

${ }^{18}$ Kozawa A. Ion-exchange adsorption of zinc and copper ions on silica. J Inorg Nucl Chem. $1961 ; 21(324): 315-324$.

${ }^{19}$ Alloteau F, Majérus O, Biron I, Lehuédé P, Caurant D, Charpentier T, et al. Temperaturedependent mechanisms of the atmospheric alteration of a mixed-alkali lime silicate glass. Corros Sci. 2019;159:108129.

${ }^{20}$ Dukhin AS, Shilov VN, Ohshima H, Goetz PJ. Electroacoustic Phenomena in Concentrated Dispersions: New Theory and CVI Experiment. Langmuir. 1999;15:6692-6706.

${ }^{21}$ Waychunas GA, Fuller CC, Davis JA, Rehr JJ. Surface complexation and precipitate geometry for aqueous $\mathrm{Zn}(\mathrm{II})$ sorption on ferrihydrite: II. XANES analysis and simulation. Geochim Cosmochim Ac. 2003;67(15):1031-1043.

${ }^{22}$ Marsalek R. Particle Size and Zeta Potential of ZnO. APCBEE Procedia. 2014;9:13-17. Available from: http://linkinghub.elsevier.com/retrieve/pii/S2212670814000049.

${ }^{23}$ Virga E, Spruijt E, De Vos WM, Biesheuvel PM. Wettability of Amphoteric Surfaces: The Effect of pH and Ionic Strength on Surface Ionization and Wetting. Langmuir. 2018;34(50):15174-15180.

This article is protected by copyright. All rights reserved. 
${ }^{24}$ Phan TNT, Louvard N, Bachiri SA, Persello J, Foissy A. Adsorption of zinc on colloidal silica, triple layer modelization and aggregation data. Colloid Surface A. 2004;244:131-140.

${ }^{25}$ Roberts DR, Ford RG, Sparks DL. Kinetics and mechanisms of Zn complexation on metal oxides using EXAFS spectroscopy. J Colloid Interf Sci. 2003;263:364-376.

${ }^{26}$ Asay DB, Kim SH. Evolution of the Adsorbed Water Layer Structure on Silicon Oxide at Room Temperature. J Phys Chem B. 2005:16760-16763.

${ }^{27}$ Robinet L, Hall C, Eremin K, Fearn S, Tate J. Alteration of soda silicate glasses by organic pollutants in museums: Mechanisms and kinetics. J Non-Cryst Solids. 2009;355(28-30):1479-1488.

${ }^{28}$ Waychunas GA, Fuller CC, Davis JA. Surface complexation and precipitate geometry for aqueous Zn(II) sorption on ferrihydrite I: X-ray absorption extended fine structure spectroscopy analysis. Geochim Cosmochim Ac. 2002;66(7):1119-1137.

${ }^{29}$ Fokkink LGJ, de Keizer A, Lyklema J. Specific ion adsorption on oxides: Surface charge adjustment and proton stoichiometry. J Colloid Interf Sci. 1987;118(2):454-462.

30 Trivedi P, Axe L, Tyson TA. An analysis of Zinc sorption to amorphous versus crystalline iron oxides using XAS. J Colloid Interf Sci. 2001;244(2):230-238.

${ }^{31}$ Kokotov M, Bar-Nachum S, Edri E, Hodes G. Effect of glass dissolution on the solution deposition of ZnO films and its exploitation for deposition of Zn silicates. J Am Ceram Soc. 2010;132(1):309-314.

${ }^{32}$ Majérus O, De Seauve V, Alloteau F, Caurant D, Lefèvre G, Lehuédé P, et al. Effect of Zn2+ and $\mathrm{Cu} 2+$ bearing salts on the dissolution of silicate glass. In: Biron I, Alloteau F, Lehuédé P, Majérus O, Caurant D, editors. Glass Atmospheric Alteration - Cultural Heritage, industrial and Nuclear Glasses. Paris: Hermann; 2019. p. 239-242. 
${ }^{33}$ Cassingham NJ, Corkhill CL, Stennett MC, Hand RJ, Hyatt NC. Alteration layer formation of Caand Zn-oxide bearing alkali borosilicate glasses for immobilisation of UK high level waste: A vapour hydration study. J Nucl Mater. 2016;479:639-646.

${ }^{34}$ Mcphail DC, Summerhayes E, Jayaratne V, Christy A. Hemimorphite solubility and stability of low-T zinc minerals. Geochim Cosmochim Ac. 2006;70(18):A414.

${ }^{35}$ Paul A. Chemical durability of glasses; a thermodynamic approach. J Mater Sci. 1977;12(11):22462268.

${ }^{36}$ Le Grand M, Ramos AY, Calas G, Galoisy L, Ghaleb D, Pacaud F. Zinc environment in aluminoborosilicate glasses by Zn K-edge extended x-ray absorption fine structure spectroscopy. J Mater Res. 2000;15(09):2015-2019.

${ }^{37}$ Cismasu AC, Levard C, Michel FM, Brown GE, Cismasu AC. Properties of impurity-bearing ferrihydrite II: Insights into the surface structure and composition of pure, Al- and Si-bearing ferrihydrite from Zn(II) sorption experiments and Zn K-edge X-ray absorption spectroscopy. Geochim Cosmochim Ac. 2013;119:46-60.

${ }^{38}$ Moezzi A, Cortie M, McDonagh AM. Formation of zinc hydroxide nitrate by H+-catalyzed dissolutionprecipitation. Eur J Inorg Chem. 2013;8(8):1326-1335.

${ }^{39}$ Li P, Xu ZP, Hampton MA, Vu DT, Huang L, Rudolph V, et al. Control preparation of zinc hydroxide nitrate nanocrystals and examination of the chemical and structural stability. J Phys Chem C. 2012;116(18):10325-10332.

\section{LIST OF FIGURES WITH LEGENDS}

Figure 1: Surface states of glass plates $\mathbf{A}$ some hours after (a), (b) a $\mathbf{Z P}$ _ spraying treatment for the two different amounts of deposited $\mathrm{Zn}^{2+}$ ions ( $\mathbf{Z P} \_\mathbf{1 . 5}$ respectively $\left.\mathbf{Z P} \_\mathbf{0 . 1}\right)$, (c) an immersion treatment

This article is protected by copyright. All rights reserved. 
(ZN_0.1). Optical images.

Figure 2: Zn in-depth profiles obtained by Tof-SIMS analysis from glass surfaces $\mathbf{A}$ (0 nm corresponds

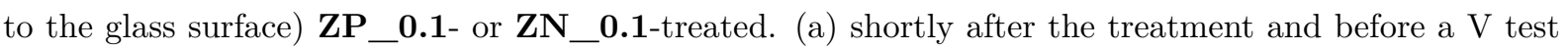
and (b) after a $\mathrm{V}$ test at $80^{\circ} \mathrm{C}, 85 \mathrm{RH} \%$, for 1 day.

Figure 3: Zn K-edge XANES spectra measured in grazing incidence to detect the $\mathrm{Zn}^{2+}$ ions deposited by spraying treatment $\left(\mathbf{Z P} \_\mathbf{0 . 1}\right)$ or by immersion $\left(\mathbf{Z N} \_\mathbf{0 . 1}\right)$ and compare their respective chemical environment. The XANES profiles of two reference samples, namely zinc hydroxide nitrate and a Zn-bearing glass are shown for comparison.

Figure 4: Zn K-edge XANES spectra of (a), (b) Zn-bearing reference samples (a glass, an aqueous solution and 5 crystalline phases), and of (b) treated glass plates $\mathbf{A}\left(\mathbf{Z P} \_\mathbf{0 . 1}\right.$ and $\left.\mathbf{Z N} \_\mathbf{0 . 1}\right)$, shortly after the treatment or after a $\mathrm{V}$ test $\left(40^{\circ} \mathrm{C}, 85 \mathrm{RH} \%\right.$, for 10 days or $80^{\circ} \mathrm{C}, 85 \mathrm{RH} \%$, for 1 day). All spectra are normalized to the same area. Similar spectral signatures are found in the literatur for $\mathrm{ZnO}, \mathrm{Zn}_{2} \mathrm{SiO}_{4}$, $\mathrm{Zn}_{5}\left(\mathrm{CO}_{3}\right)_{2}(\mathrm{OH})_{6}$ and $\mathrm{Zn}^{2+}{ }_{\text {aq. }}{ }^{37}$

Figure 5: Surface states of glass plates A several weeks after a $\mathrm{V}$ test at $80^{\circ} \mathrm{C}, 85 \mathrm{RH} \%$ for 1 day. (a) untreated before the $\mathrm{V}$ test. (b), (c) and (d) $\mathbf{Z P} \_\mathbf{1 . 5}$-treated, $\mathbf{Z P} \_\mathbf{0 . 1}$-treated and $\mathbf{Z N}$ _0.1-treated respectively before the $\mathrm{V}$ test. Optical images.

Figure 6: FTIR spectra in transmission mode obtained on pristine or on aged glass plates A (untreated or treated before the $\mathrm{V}$ test at $80^{\circ} \mathrm{C}, 85 \mathrm{RH} \%$, for 1 day).

Figure 7: Zn K-edge XANES spectra of (a) ZN_0.1- or (b) ZP_0.1-treated glass plates and aged at

This article is protected by copyright. All rights reserved. 
$80^{\circ} \mathrm{C}, 85 \mathrm{RH} \%$ for 1 day. For each of these spectra, a spectrum simulated by linear combination of the respective spectrum of reference compounds glass $\mathbf{A}_{\mathbf{Z n}}, \mathrm{Zn}_{5}(\mathrm{OH})_{8}\left(\mathrm{NO}_{3}\right)_{2} \cdot \mathrm{H}_{2} \mathrm{O}$ or by the unaged ZN_ 0.1-treated glass plate is displayed.

Figure 8: Possible structural configuration of $\mathrm{Zn}^{2+}$ ions bonded to the silicate network in the glass nearsurface after a $\mathrm{V}$ test $\left(80^{\circ} \mathrm{C}\right.$ or $\left.40^{\circ} \mathrm{C}, 85 \mathrm{RH} \%\right)$. This configuration is inspired from the local environment of $\mathrm{Zn}^{2+}$ ions in silicate glasses described in Ref. ${ }^{36}$

\section{TABLES WITH LEGENDS}

\begin{tabular}{|c|c|c|c|c|}
\hline Name & Type of treatment & Glass sample & {$\left[\mathrm{Zn}^{2+}\right]_{\text {sol }}(\mathrm{mM})$} & {$\left[\mathrm{Zn}^{2+}\right]_{\text {surf }}\left(\mu \mathrm{g} / \mathrm{cm}^{2}\right)$} \\
\hline $\mathrm{ZP} \_1.5$ & spraying & plate & 9 & $1.5 \pm 0.1$ \\
\hline $\mathrm{ZP} \_0.1$ & spraying & plate & 0.61 & $0.1 \pm 0.03$ \\
\hline $\mathrm{ZN} \_0.1$ & immersion & plate or powder & 1.2 & $0.1 \pm 0.03$ \\
\hline
\end{tabular}

Table 1: Description of the studied treatments based on $\mathrm{Zn}\left(\mathrm{NO}_{3}\right)_{2} \cdot 6 \mathrm{H}_{2} \mathrm{O}$ (name, glass sample for the deposit ie plate or powder, $\mathrm{Zn}^{2+}$ ions concentration in the treatment solution and $\mathrm{Zn}^{2+}$ ions concentration deposited on glass surface).

This article is protected by copyright. All rights reserved. 


\begin{tabular}{|c|c|c|}
\hline Reference compound & $\begin{array}{l}\text { Coordination } \\
\text { number of } \mathrm{Zn}^{2+}\end{array}$ & Preparation \\
\hline $\mathrm{ZnO}$ & & \\
\hline $\begin{array}{l}\text { zincite } \\
\mathrm{Zn}_{5}\left(\mathrm{CO}_{3}\right)_{2}(\mathrm{OH})_{6}\end{array}$ & IV & commercial powder \\
\hline hydrozincite & IV,VI & commercial powder \\
\hline $\begin{array}{l}\mathrm{Zn}_{5}(\mathrm{OH})_{8}\left(\mathrm{NO}_{3}\right)_{2} \cdot 2 \mathrm{H}_{2} \mathrm{O} \\
\text { zinc hydroxide nitrate hydrate }\end{array}$ & $\mathrm{IV}, \mathrm{VI}$ & $\begin{array}{l}\text { powder synthetized by precipitation of } \\
\mathrm{Zn}\left(\mathrm{NO}_{3}\right)_{2} \cdot 6 \mathrm{H}_{2} \mathrm{O}, \mathrm{ZnO} \text { and } \mathrm{NaOH}^{38}\end{array}$ \\
\hline $\begin{array}{l}\mathrm{Zn}(\mathrm{OH})_{2} \\
\text { zinc hydroxide }\end{array}$ & IV & $\begin{array}{l}\text { powder synthetized by precipitation of } \\
\qquad \mathrm{Zn}\left(\mathrm{NO}_{3}\right)_{2} \cdot 6 \mathrm{H}_{2} \mathrm{O} \text { and } \mathrm{NaOH}^{39}\end{array}$ \\
\hline $\begin{array}{l}\mathrm{Zn}_{2} \mathrm{SiO}_{4} \\
\text { willemite }\end{array}$ & IV & $\begin{array}{l}\text { powder synthetized by sintering of } \\
\mathrm{ZnO} \text { and } \mathrm{SiO}_{2} \text { at } 1400^{\circ} \mathrm{C} \text { during } 24 \mathrm{~h}\end{array}$ \\
\hline $\begin{array}{l}\mathrm{A}_{\mathrm{Zn}} \\
\text { glass } \boldsymbol{A} \text { containing zinc* }\end{array}$ & IV & $\begin{array}{c}\text { glass synthetized in laboratory and } \\
\text { powdered }\end{array}$ \\
\hline $\mathrm{Zn}^{2+}{ }_{\mathrm{aq}}$ & VI & $\begin{array}{l}\text { aqueous solution of } \mathrm{Zn}\left(\mathrm{NO}_{3}\right)_{2} \cdot 6 \mathrm{H}_{2} \mathrm{O} \\
\qquad 10 \mathrm{mM}\end{array}$ \\
\hline
\end{tabular}

Table 2: Reference compounds for the XANES experiments performed at the SOLEIL synchrotron (SAMBA line). ${ }^{*}$ glass $\mathbf{A}$ with a substitution of 2.6 wt\% of $\mathrm{SiO}_{2}$ by $\mathrm{ZnO}$ : (wt\%) $\mathrm{SiO}_{2} 68.9, \mathrm{Na}_{2} \mathrm{O}$ 11, $\mathrm{K}_{2} \mathrm{O}$ 11, $\mathrm{CaO} 5, \mathrm{ZnO} 2.6, \mathrm{MgO} 0.8, \mathrm{Al}_{3} \mathrm{\rho}_{3} 0.8$ (composition checked by EDX).

This article is protected by copyright. All rights reserved. 


\begin{tabular}{ccc}
\hline $\mathrm{pH}$ & untreated & ZN_0.1-treated \\
\hline 10.3 & $-23.8 \mathrm{mV}$ & $-3.9 \mathrm{mV}$ \\
7.9 & $-9.9 \mathrm{mV}$ & $-1.3 \mathrm{mV}$ \\
& & $-2.3 \mathrm{mV}$ \\
7 & $-8.2 \mathrm{mV}$ & \\
& & $-4.8 \mathrm{mV}$ \\
5 & $-6.8 \mathrm{mV}$ & \\
\hline
\end{tabular}

Table 3: Zeta potentials measured from solutions of untreated or ZN__0.1-treated glass powders, for different $\mathrm{pH}$ values.

This article is protected by copyright. All rights reserved. 


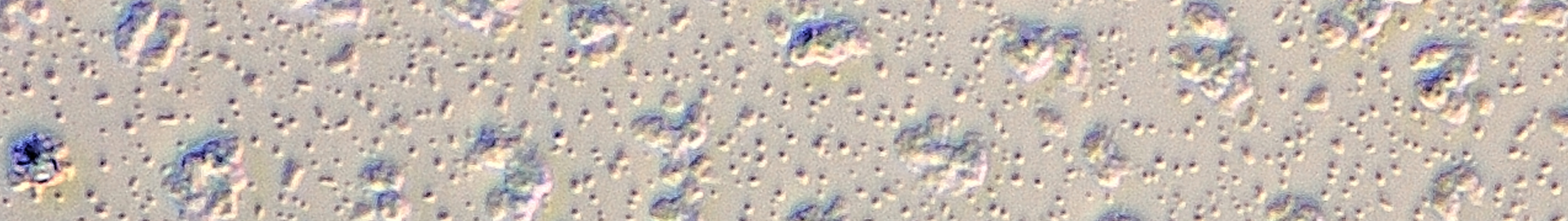

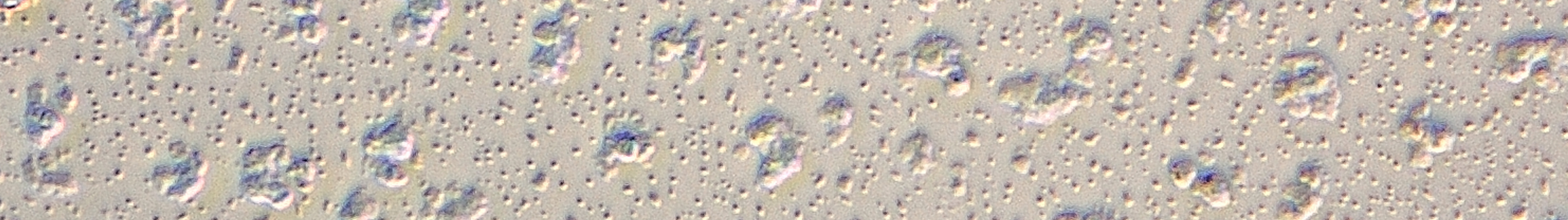

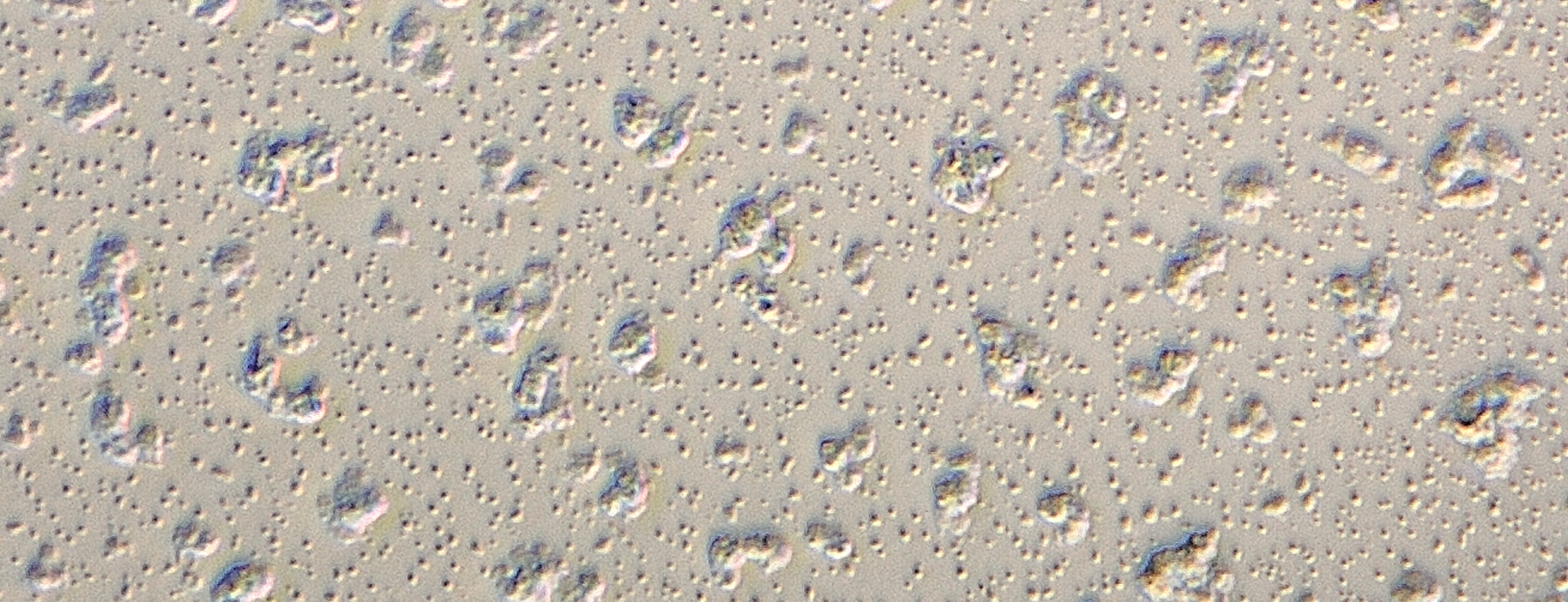






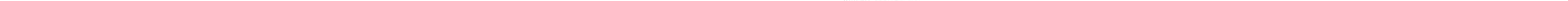




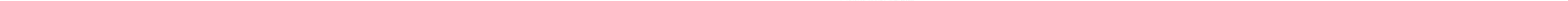




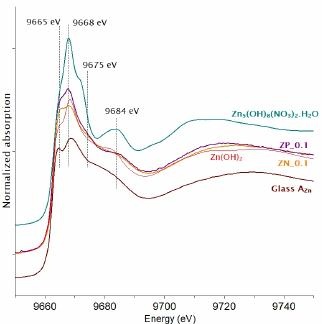




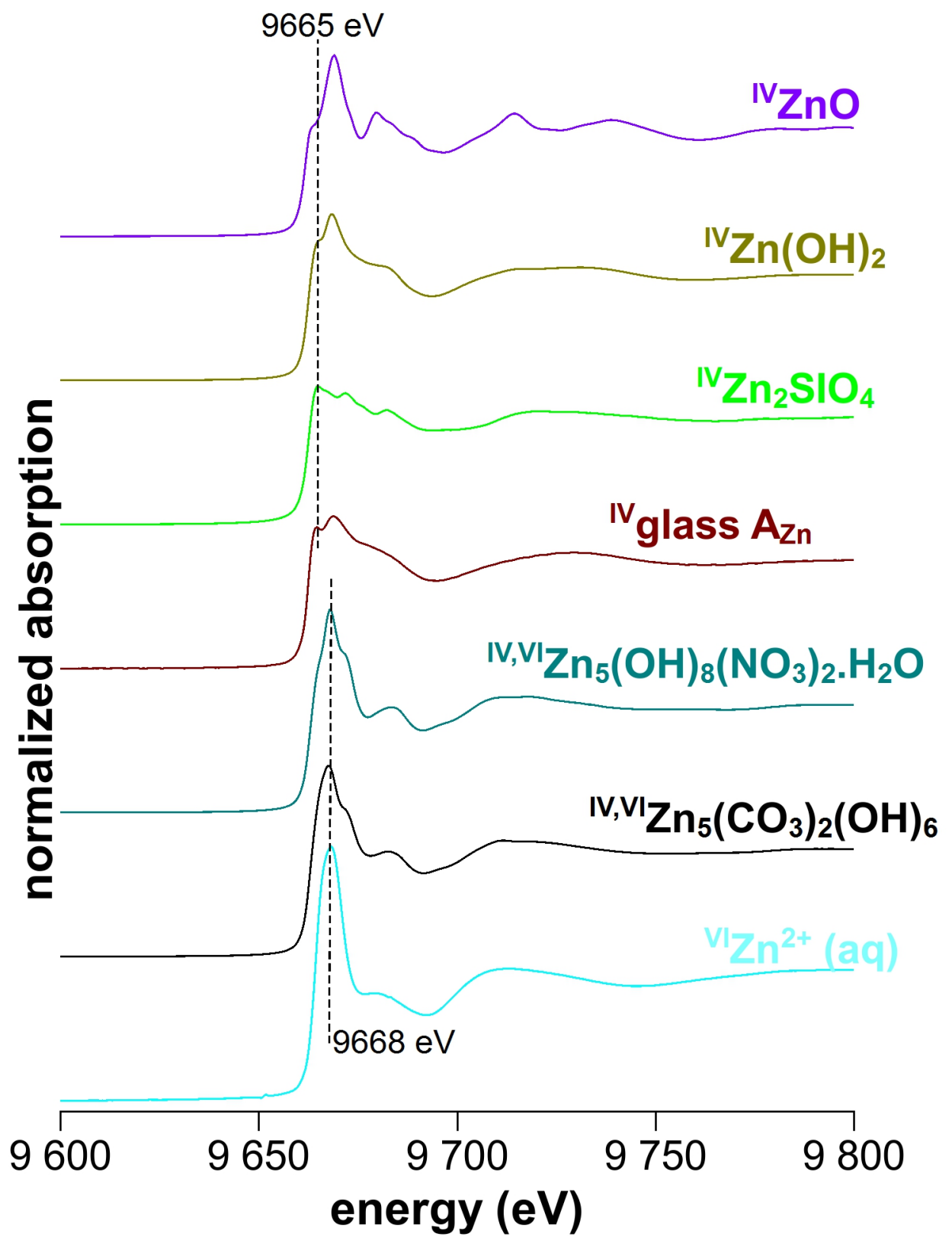




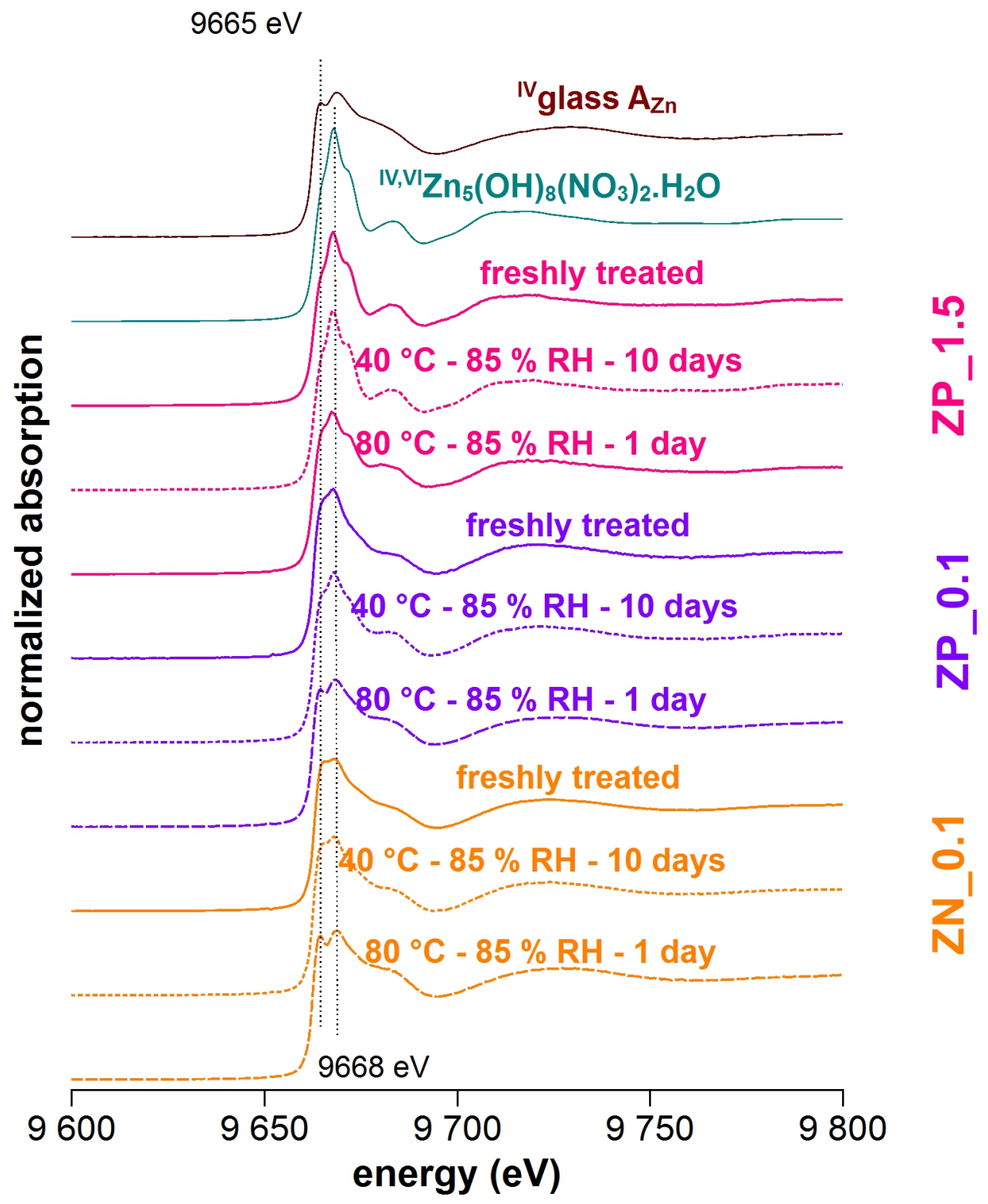




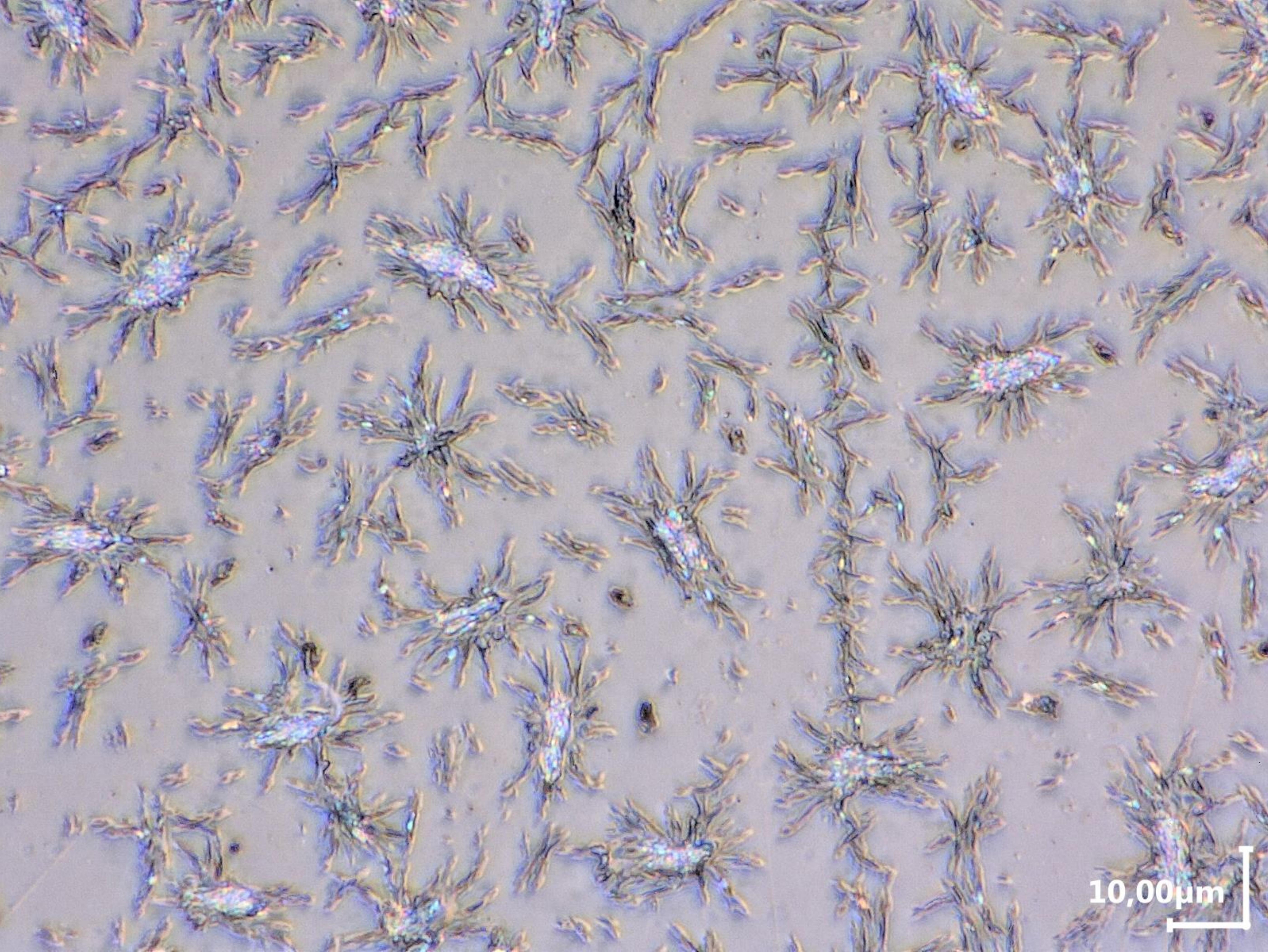




Q 


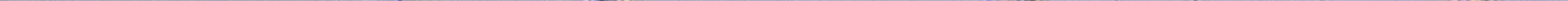




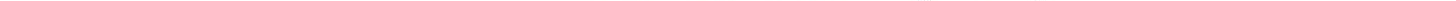




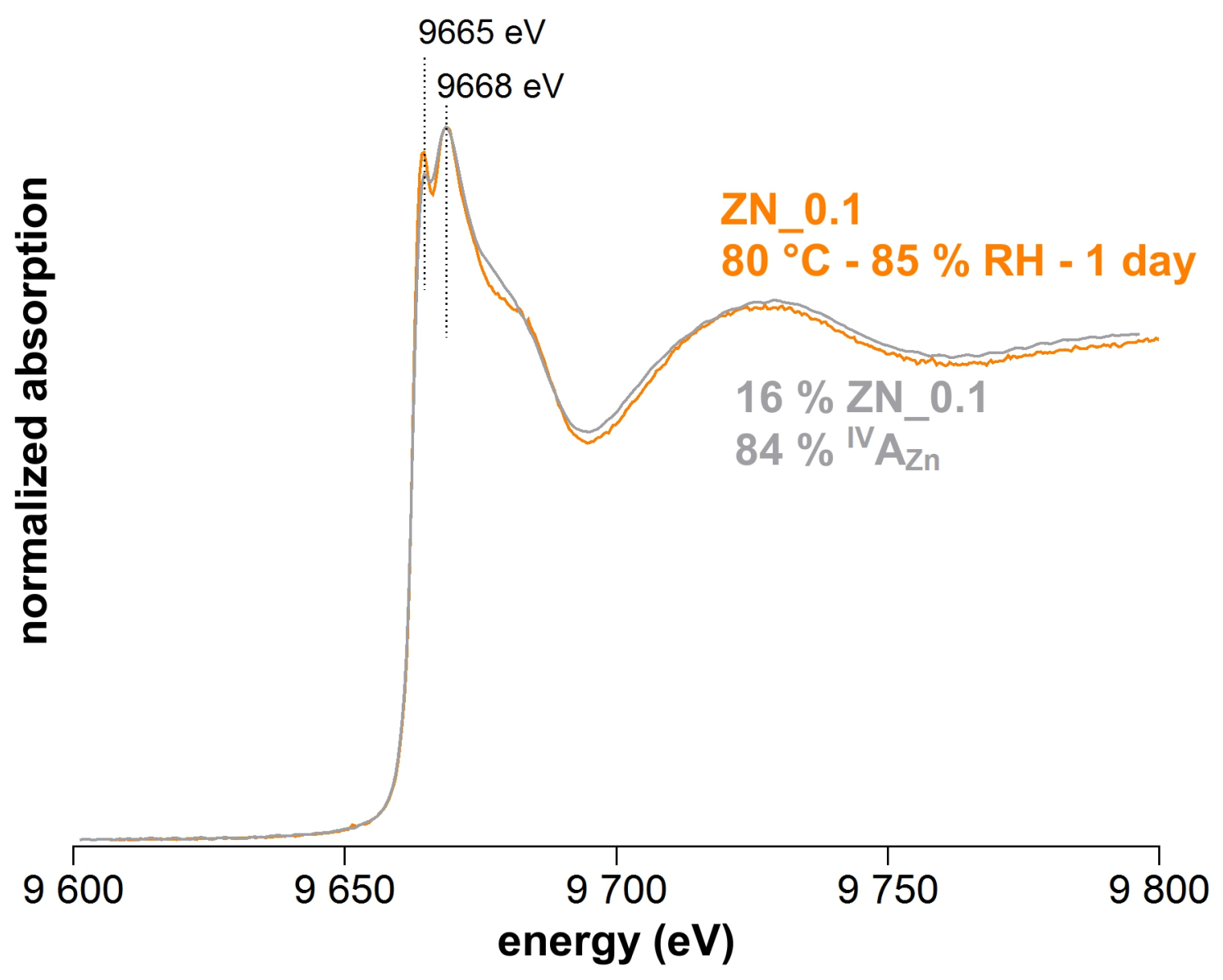


$9665 \mathrm{eV}$

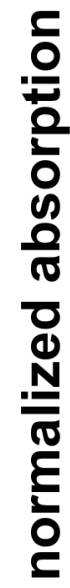
$9668 \mathrm{eV}$

\section{$89 \%{ }^{\mathrm{IV}} \mathrm{Azn}_{\mathrm{zn}}$

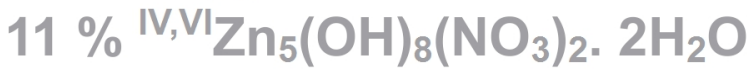

9600

9650 


\section{Si}

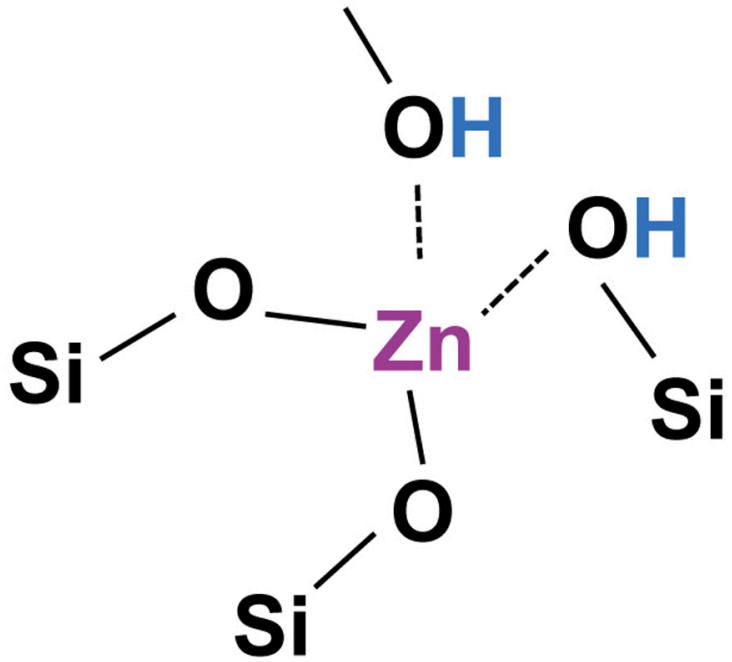

